\title{
Epistemology Study: The Role of Christian Teachers Regarding Students Freedom in Learning
}

\author{
Kajian Epistemologi: Peran Guru Kristen terhadap Kebebasan Belajar Siswa
}

Author:
- Nabylla Sardy ${ }^{1}$
- Neng Priyanti

Affiliation:
1 Universitas Pelita
Harapan Jakarta
nabyllasardy08@gmail.com
2 Universitas Pelita
Harapan Jakarta
neng.priyanti@uph.edu

Dates:
Submitted:
16 November 2020
Accepted:
6 April 2021
Published:
17 May 2021
Copyright:
4.0 International License.
Creative Commons
Licensee: Licensee:
PASCA. This work is
DOI:
10.46494/psc.v17i1.122

Abstract: School epistemological belief is essential as it directly influences the goal and center of education. Following this logic, Christian education ideally aims to guide students to the knowledge of God as Christian epistemology believes that God is the source of knowledge. However, in teaching and learning practices, Christian teachers may be unaware of the world's modern philosophy and thus unconsciously adopt the practices from the modern educational approach. As a result, the goal of Christian education can be shifted from God-centered to student-centered learning within progressive educational practice. Misleading knowledge and truth may bring schools away from the responsibility to fulfill God's will in education. Thus, it is necessary for Christian teachers to guide students throughout the learning process to see God as the source of knowledge. This paper aims to critically discuss the Christian teachers' role as a guide regarding students' freedom in learning. To this end, this study employs a literature review method. The study concludes that Christian teachers can exercise the God-given authority to guide students in using their intellectual and free-will to serve God and others.

Research Contribution: This research helps Christian schools to be more aware of educational philosophy that contradicts Biblical views about knowledge in order for schools to guide students away from relative interpretations of the truth and towards absolute truth.

Keywords: Christian education, pragmatism, progressive education, teachers' role, freedom learning.

\section{Introduction}

$\mathrm{E}$ pistemology, as one of the branches in the philosophy, is closely related to education. It studies the nature of knowledge, how humans can acquire knowledge, and the limitation of human knowledge, and the limitation of human knowledge. Education, on the other hand, deals with knowledge and the acquisition of knowledge by the general population. Thus, epistemology and education are related because both relate to human knowledge. In fact, school epistemological belief will directly influence the goal and center of education. As Christian epistemology believes that God is the source of knowledge and the beginning of all existence, Christian education therefore aims to guide students to the knowledge of God as the center of learning. 
Aligned with the goal of Christian education, Christian teachers need to first understand their role as a guide in the teaching process. They are responsible to guide students to know God personally and lead them to understand the true knowledge which is rooted in God's revelation of Himself as the source of knowledge (Colossians 2: 3). By exercising their roles, it is expected that students have the foundation to develop their understanding of any given subject in school. ${ }^{1}$ However, Christian teachers as fallen human beings are finite, understanding the world and what is in it seems to be an impossible task. ${ }^{2}$

In fact, in their teaching and learning practices, Christian teachers may be unaware of the world's modern philosophy and thus unconsciously adopt the practices from the modern educational approach. Such lack of unawareness affects the goal of Christian education, shifting its goal from God-centered learning to human-centered. For instance, progressive education-based on the pragmatism philosophical belief-has been viewed as an alternative to educational approach in promoting student-centered learning. ${ }^{3}$ John Dewey as one of the primary figures associated with the philosophy of pragmatism argues that student's active experience should be the center of learning. 4 Within this approach, students are given freedom to choose their subject interests and

\footnotetext{
${ }^{1}$ Khoe Yoa Tung, Filsafat Pendidikan Kristen: Meletakkan Fondasi Dan Filosofi Pendidikan Kristen Di Tengah Tantangan Filsafat Dunia (Yogyakarta: ANDI, 2013).

2 Donovan L. Graham, Teaching Redemptively: Bringing Grace and Truth into Your Classroom (Colorado Springs: Purposeful Design Publications, 2009).

3 Morgan Williams, "Dewey in the 21 St Century," Journal of Inquiry \& Action in Education 9, no. 1 (2017): 91-102.

4 John Pecore and Bertram Bruce, "Editorial for Progressive Education: Antecedents of Educating for Democracy," International Journal of Progressive Education 9, no. 1 (2013): 10-13.

5 Lucian Radu, "John Dewey and Progressivism in American Education," Bulletin of the Transilvania
}

learning activities, concerning their personal experiences. 5 In addition, students' continuous life experiences is considered as the only authentic source of knowledge. ${ }^{6}$ Students will have the authority to construct their knowledge and truth through self-exploration. As a result, truth will be relative to one's perspective and dependent upon human daily interaction.

In a study of the impact of Pragmatism in education, Hao argues that progressive education promotes more effective learning as students have the freedom to study school subjects at their own pace and the flexibility in building individual learning framework.7 In Indonesia, progressive learning is highly recommended by the government as it is considered to be more meaningful for students given that students can freely enrich and construct their knowledge. Another recent study also added that Indonesia's biggest challenge regarding education is to improve learning quality so students can learn best from what they consider most relevant to their lives. ${ }^{8}$ For instance, progressivists centered the curricula on students' needs, experiences, and abilities.

Thus, progressive education at its core contradicts Christian education since the main focus of learning has shifted. Progressive education does not appear to represent God as the center of learning and the ultimate source of knowledge. To be more specific, progressive

\footnotetext{
University of Braşov, Series VII: Social Sciences and Law 4, no. 2 (2011): 85-90.

${ }^{6}$ Aliya Sikandar, "John Dewey and His Philosophy of Education," Journal of Education and Educational Development 2, no. 2 (2016): 191-201, https://doi.org/10.1080/00131725309341597.

7 Jian-Jun HAO, "A Study of the Impact of Pragmatism on American Education," DEStech Transactions on Social Science, Education and Human Science, no. icesd (2017): 346-49,

https://doi.org/10.12783/dtssehs/icesd2017/11565.

${ }^{8}$ Hasan Mustapa, Riska Maelani, and Iman Saefullah,

"Indonesian Human Progressivism : Human Resources Quantity in Educational Philosophy Perspective," Jurnal Pendidikan Universitas Garut 13, no. 01 (December) (2019).
} 
schools focus only on the students' personal needs and interests. What is more contradictory is that progressive practice is merely underpinned on the pragmatism philosophy which believes that there is no absolute truth and that human experience is the source of knowledge. As a result, students in progressive education will have freedom in acquiring knowledge based on their relative interpretation of truth.

Unlike progressive education, Christian education is aimed not only to meet students' interests and needs but also to instill the true knowledge within a Biblical worldview. The Bible must serve as a lens in building the framework to study any particular subject in the classroom. ${ }^{9}$ As God reveals Himself in the Bible and through His creations, the truth in the Christian belief and the natural world is consistent. This Biblical infallibility points to the impossibility of error and the absolute authority of the Bible as a whole. ${ }^{10}$ Likewise, facts and truth discovered in many different ways will not contradict the absolute truth.11 Through a Biblical framework, both teachers and students are supposed to see God as the focus of all knowledge, since by Him all things exist (Colossians 1: 17). Christian education should therefore reveal the consistent and absolute truth in God throughout all the teaching and learning processes.

In exercising their roles, Christian teachers need to see every student as the image of God that possesses God-given intellectual and free will. ${ }^{12}$ Such views suggest that urgency for

9 Graham, Teaching Redemptively: Bringing Grace and Truth into Your Classroom.

${ }^{10}$ Djoko Sukono, "Alkitab: Penyataan Allah Yang Diilhamkan," PASCA : Jurnal Teologi Dan Pendidikan Agama Kristen 15, no. 1 (2019): 28-34,

https://doi.org/10.46494/psc.v15i1.66.

${ }^{11}$ Alvin Plantinga, Faith and Rationality: Reason and Belief in God (Notre Dame: Univ. of Notre Dame Press, 2014).

${ }_{12}$ Stephen Tong, Arsitek Jiwa 1: Guru Sekolah Minggu \& Guru Agama Kristen (Surabaya: Lembaga Reformed Injili Indonesia, 2003).
Christian teachers to address students' needs and interests but not making such needs and interests as the center of learning. In other words, in students' search for truth and meaning, teachers need to provide clear guidance and thus use Bible as its framework. It means that students can participate actively in their own learning, but teachers have the authority to set the boundaries in the classroom. This should be done intentionally and with clarity so that God's truth is not replaced with students' self-constructed truth. ${ }^{13}$

This paper in particular aims to describe Christian teachers' roles in the classroom regarding students' freedom in learning. It begins with the discussion of the current progressive educational practice that promotes student-centered learning focusing more on students' freedom in acquiring knowledge within their relative interpretation of truth. It then continues with the discussion of teachers' role in guiding students to use their God-given intellectual and free will for God's glory.

\section{Methods}

The method used in this research is literature review, through building and interpreting previous studies. ${ }^{14}$ Literature reviews are useful in providing knowledge and overview of the proposed research problem. ${ }^{15}$ This research will synthesize findings from relevant study of progressive education and Christian education epistemological belief. By critical analysis ${ }^{16}$, this

13 George R. Knight, Filsafat \& Pendidikan (4th Ed.)

(Jakarta: Universitas Pelita Harapan, 2009).

${ }_{14}$ Sonny Eli Zaluchu, "Metode Penelitian Di Dalam Manuskrip Jurnal Ilmiah Keagamaan," Jurnal Teologi Berita Hidup 3, no. 2 (March 25, 2021): 249-66, https://doi.org/10.38189/jtbh.v3i2.93.

${ }^{15}$ Hannah Snyder, "Literature Review as a Research Methodology: An Overview and Guidelines," Journal of Business Research 104, no. August (2019): 333-39, https://doi.org/10.1016/j.jbusres.2019.07.039. ${ }^{16}$ Marvin Gilbert, "Integrative Critical Analysis," in Missiological Research: Interdiisciplinary Foundations, 
research will discuss the argument on the crucial role of Christian teachers regarding students' freedom in learning.

\section{Discussion}

\section{Epistemology and Pragmatism}

Epistemology is one of the branches in philosophy along with metaphysics, axiology, and logic. The study of epistemology concerned with the nature, origin, and justification of knowledge. ${ }^{17}$ Some crucial questions of epistemology will be 'What is knowledge?', 'Why does knowledge have certain features?' and 'How knowledge can be applied?'. Consequently, epistemology is required in order to be able to understand how humans can acquire knowledge and the limitation of human knowledge. There are two ways of gaining knowledge determined by its source; first, $a$ piori, where knowledge is independent from human experience and follows from presupposed truth principles or God-given truth. On the other hand, a posteriori, where knowledge is gained from human experience or from studies based on human perception. ${ }^{18}$

Christian religious belief can be justified without much further evidence and rationally grounded. God created humans with a sensus divinitatis, which is the ability to know Him as the beginning of all things, including knowledge. ${ }^{19}$ Sensus divinitatis is the source of the basic knowledge of God that will enable humans to believe in God. The fear of the Lord is the beginning of knowledge; therefore, the Bible serves as the foundation of all knowledge
(Proverbs 9: 10). However, human knowledge is not neutral; some believe that knowledge depends on humans' personal interpretation of truth and reality. ${ }^{20}$ The belief that views knowledge as relative and subjective, rather than absolute, is called pragmatism.

Pragmatism is one of the philosophical views that arguably contradicts with Christian epistemology. It views knowledge as subjective, thus, underpinning the true knowledge based on human daily interaction and experience. ${ }^{21}$ In other words, knowledge and truth will be dependent upon human action. The philosophers of pragmatism are Charles Sanders Pierce (1839-1914), William James (1842-1910), and John Dewey (1859-1952); Dewey, then became the most prominent philosopher of pragmatism due to his continual work contributions in pragmatism, especially in the educational field. ${ }^{22}$

There are three important characteristics of pragmatism; first, human experience is the only reality and there is nothing absolute or a piori. ${ }^{23}$ Second, truth relies on something useful as humans will continue to interact with their surroundings. Third, values that exist in society are determined by humans' dynamic life experiences. Each person's knowledge is influenced by their personal experiences in society; as a result, all truth is socially constructed. The truth will be justified if it has been proven to be beneficial and helpful in fulfilling human needs. Then, through human interaction, truth and value are shaped as a shared belief in society. For pragmatists,

2o Haro Van Brummelen, Batu Loncatan Kurikulum: Berdasarkan Alkitab (2nd Ed.) (Jakarta: Universitas Pelita Harapan, 2008).

${ }^{21}$ Knight, Filsafat \& Pendidikan (4th Ed.).

22 Gert Biesta and Nicholas Burbules, Pragmatism and Educational Research (Lanham: Rowman \& Littlefield, 2013).

23 Wasitohadi Wasitohadi, "Pragmatisme, Humanisme Dan Implikasinya Bagi Dunia Pendidikan Di Indonesia,” Satya Widya 28, no. 2 (2012): 175-90, https://doi.org/10.24246/j.sw.2012.v28.i2.p175-190. 
knowledge depends solely on human experience and relative interpretation of reality.

\section{Philosophy of Progressive Education}

Progressivism is an educational movement that seeks to go beyond traditional school by promoting a student-centered learning experience. ${ }^{24}$ In the traditional classroom, students will passively receive the knowledge delivered by teachers. By contrast, progressive education promotes students' active learning in the classroom. It was based on John Dewey's pragmatism philosophy of progressive education in America during the $20^{\text {th }}$ century. Dewey argues that students' active experience is the center of learning, aligned with the purpose of education-to prepare students for their future as a good and democratic citizen. ${ }^{25}$

There are some main characteristics of progressive education; firstly, a studentcentered approach, which means the needs of the student serve as the center of learning. ${ }^{26}$ Secondly, students' needs and interests influence the learning goals and school curriculum. Thirdly, students must have the freedom to grow and learn from their daily experiences. School, as part of students' life, is a place where students can actively reconstruct and reorganize their life experiences to promote personal growth. ${ }^{27}$ Within the Progressive education, students' active learning is facilitated through the continuous adjustment of the learning processes and activities intentionally done by the educational institutions to meet the needs of the students.

\footnotetext{
24 Radu, "John Dewey and Progressivism in American Education."

25 William Jeynes, The Wiley Handbook of Christianity and Education (Hoboken: Wiley, 2018); Pecore and Bruce, "Editorial for Progressive Education: Antecedents of Educating for Democracy." ${ }^{26}$ Norman D. Norris, The Promise and Failure of Progressive Education (Lanham: Scarecrow Press/Rowman \& Littlefield Pub, 2004).

27 Wasitohadi, "Pragmatisme, Humanisme Dan Implikasinya Bagi Dunia Pendidikan Di Indonesia."
}

Focusing on experiential learning, progressive education creates meaningful learning environment to support students' active and participative exploration. In other words, it puts greater emphasis on students' freedom in learning, allowing students to freely search and make meaning of their learning. ${ }^{28}$ As students will have the authority to freely construct their knowledge through the process of exploring and acquiring personal meaning, true knowledge is therefore relative to one's interpretative judgement. This is so as students have different experiences, needs and background, thus truth constructed from such self-exploration will therefore be relative and thus subjective. ${ }^{29}$

\section{Teachers' Role in Progressive Education}

Teachers' main role in progressive education is as students' facilitators. As students' facilitators, teachers' authority in the classroom will be, as its name suggests, limited. Teachers are not authoritarian but rather act as facilitators that encourage students to develop their independence and autonomy. 30 To be more specific, in progressive classrooms, teachers create classroom environment which promotes freedom in learning which includes students' active discovery of their interest and potential, students' active participation in searching for knowledge, and students' ability to actively act following their roles in society. ${ }^{1}$

For the progressivist, focusing on students' active participation will create more meaningful learning. Students need to have the freedom to choose their subject interest and class activity

\footnotetext{
${ }^{28}$ Ahmed A Osman, "Freedom in Teaching and Learning," International Journal of Humanities and Social Science 3, no. 2 (2013): 142-49.

29 Khoe Yoa Tung, Menuju Sekolah Kristen Impian Masa Kini (Yogyakarta: ANDI, 2014).

30 Biesta and Burbules, Pragmatism and Educational Research.

${ }^{31}$ Robert W Pazmiño, God Our Teacher: Theological Basics in Christian Education (Grand Rapids: Baker Academic, 2002).
} 
that is suitable for their own needs. 32 Accordingly, teachers in progressive schools should be able to create an active learning environment in which students can freely enrich their life experiences. In progressive classrooms, students may freely construct and interpret their own knowledge found in students' personal experiences. Thus, teachers need to create meaningful teaching and learning activities that are inseparable from students' personal experiences.

Based on the pragmatism philosophy, all learning processes in progressive classrooms must provide rich and meaningful experiences for students.33 Consequently, schools could promote individual development through the process of students' active research and discovery. The classroom is believed as a progressive process when students can encounter and connect to authentic real-life experiences. In the classroom, teachers are considered as fellow learners who will learn and enrich their personal experiences. 34

\section{Philosophy of Christian Education}

In the philosophy of Christian education, the primary purpose of all teaching and learning processes is to bring students to understand the knowledge of God. Education is supposed to be for God's glory; thus, the Bible should serve as the foundation of learning. 35 A Christ-centered approach in learning reflects a distinctively Christian education from other forms of education. Christian schools that are rooted in the Scripture will guide students towards an understanding that God is the center of

\footnotetext{
32 Radu, "John Dewey and Progressivism in American Education."

33 Williams, "Dewey in the 21 St Century."

34 Robert W Pazmiño, Foundational Issues in Christian Education, Heritage (Grand Rapids: Baker Academic, 2008).

35 Jeynes, The Wiley Handbook of Christianity and Education.

${ }^{36}$ Haro Van Brummelen, Walking with God in the Classroom, Walking with God in the Classroom (Jakarta: Universitas Pelita Harapan, 2009).
}

knowledge. ${ }^{6}$ In other words, through a Christian worldview, students can understand that the Bible provides an unifying perspective of all knowledge.

There are three nature of Christian education; first, the Bible is the central foundation of education. 37 Each area of study should help students to see God's providence and revelation of Himself in His creation. Second, Christian education focuses on emphasizing both students' horizontal and vertical relationships. The horizontal symbolizes students' personal relationships with others, while the vertical represents students' personal or communal relationship with God. Third, Christian education guides students to realize the supernatural and transcendent existence of God. God who reveals Himself in the Bible is the Triune God who is eternally Father, Son, and Holy Spirit. $3^{8}$ It means that throughout all the teaching and learning processes, Christian education should introduce the students to God the creator of all beings.

The nature of Christian education then suggests different purposes of education with the secular ones, particularly progressive. Progressive mainly focused on students' needs and interests by promoting student-centered learning. Moreover, progressive promotes students' active learning, in which students could build their own knowledge within the relative interpretation of truth.39 Christian education, on the other hand, seeks to guide students within Christ-centered learning. The Bible is the

\footnotetext{
37 John Kwaku Opoku, Peter Addai-mensah, and Eric Manu, "Realization of the Nature and Role of Christian Education in Modern Pedagogy," British Journal of Education 2, no. 5 (2014): 26-35.

$3^{8}$ Eko Wahyu Suryaningsih, "Doktrin Tritunggal Kebenaran Alkitabiah,” PASCA : Jurnal Teologi Dan Pendidikan Agama Kristen 15, no. 1 (2019): 16-22, https://doi.org/10.46494/psc.v15i1.64.

39 Rebecca Garte, "American Progressive Education and the Schooling of Poor Children: A Brief History of a Philosophy in Practice," International Journal of Progressive Education 13, no. 2 (2017): 7-17.
} 
foundation on which all the teaching and learning practices are built.

The fact that Christian education has a distinctive aim of education also leads to a different perspective on viewing the learners. There are several essential points in viewing the students; firstly, every student is created in the image of God who can possess knowledge, righteousness, and holiness from God (Ephesians 4: 24).40 Secondly, every student has different God-given potentials that needed to be facilitated. Thirdly, students are a finite and fallen creation. Fourthly, every student is able to learn and transform from their mistakes with the help of the Holy Spirit and the guidance from teachers. Finally, each student is responsible for all of their actions. The correct perspective of viewing the students will guide Christian education to fulfill God's aim in education.

\section{Teachers' Role in Christian Education}

Unlike in progressive education, Christian teachers' role is more than just students' facilitator. Christian teachers serve as the guide for students to be responsible and responsive disciples of Christ. ${ }^{11}$ Other than that, teachers are expected to guide students to be faithful disciples of God that will glorify Him², which is as written in 1 Peter 4: 10 "Each of you should use whatever gift you have received to serve others, as faithful stewards of God's grace in its various forms (NIV)". Every student will have unique potential that needs to be addressed and guided for the right purpose. Accordingly, Christian teachers are given the responsibility to guide students to become a

\footnotetext{
40 Pazmiño, Foundational Issues in Christian Education.

${ }^{41}$ Brummelen, Walk. with God Classr.

$4^{2}$ Ferry Yang, Pendidikan Kristen (Surabaya:

Momentum, 2018).

43 Brummelen, Batu Loncatan Kurikulum:

Berdasarkan Alkitab (2nd Ed.).

44 Pazmiño, Foundational Issues in Christian

Education.
}

faithful Christ disciple who maximizes their personal gifts for serving God and others. 43

In their teaching practice, teachers should therefore guide students based on the true foundation. As Christian education put Bible as its source of its truth, teachers should make the Biblical framework as its foundation of learning as well44, affecting all the learning process happening in the classroom. Such Biblical foundation however contradicts with the nature and the principle of progressive education which views truth something constructed and thus relative. Christians put knowledge and wisdom revealed by the ultimate source in Christ as the truth (Colossians 2: 3) regardless of its presumably lack of empirical evidence. The true knowledge and truth will depend on God's revelation and are reflected in His creation.45 God is the source of all truth; therefore, all subject inquiries are related to God.

As Christian education aims to bring students to be disciple of Christ, Christian teachers should therefore model Jesus' teaching in exercising their role as a guide. ${ }^{46}$ In His earthly ministry, Jesus was viewed as a great teacher who always proclaim the truth in God. There are several principles of Jesus's teaching; firstly, Jesus' teaching was authoritative but not authoritarian. 47 Secondly, Jesus' teaching encouraged His disciples' curiosity and discovery. Thirdly, Jesus taught His listeners using examples. Finally, Jesus loved His followers. Jesus lived His teachings and demonstrated what He taught. Jesus' authority demonstrated in His teaching, which is the Bible. Accordingly, all the learning processes in

\footnotetext{
45 Brummelen, Batu Loncatan Kurikulum: Berdasarkan Alkitab (2nd Ed.).

${ }^{46}$ Ronald T. Habermas, Introduction to Christian Education and Formation: A Lifelong Plan for ChristCentered Restoration (Grand Rapids: Zondervan, 2008). 47 Michael Anthony, Introducing Christian Education: Foundations for The Twenty-First Century (Baker Academic, 2001).
} 
Christian education seek to guide students to be disciples of Christ; thus, as a guide, teachers ought to model Jesus' teaching.

Taking all of that to the classroom context, Christian teachers have the authority to guide the learning processes based on the absolute foundation. To develop reasoning and thinking, students are of course encouraged to pose questions and be given critical answers to deepen students' understanding of the world within the biblical worldview. Such authoritative teaching and guiding of Christian teachers allow students to search and build their own knowledge within the right framework. In other words, Christian teachers lead students in their discovery within the absolute and authoritative truth.

\section{Christian Epistemology: \\ Teachers Role in Learning}

Philosophy in education is essential because it underpins and directly influences the goal of education. 48 The goal of education is viewed to be educating students in the process of acquiring knowledge and developing individual potential. However, different forms of education will focus on different goals of education. Moreover, the view of knowledge and truth will also be distinct. In Christian education, the discussion about knowledge and truth should be driven by the Christian epistemology. On the other hand, progressive education focuses on human relative interpretations of truth. Contrasting Christian education and progressive education epistemological belief leads to different teaching-learning approaches, specifically concerning the role of teachers in the classroom.
Progressive education is rooted in the pragmatism philosophical belief.49 For pragmatists, human personal experience is considered the most reliable source of knowledge and truth. Furthermore, the justification of truth solely depends on its practical and beneficial function in fulfilling human needs.50 Based on the pragmatism philosophy, progressive education aimed to foster students' continuous process of enriching personal experience. Then, all the learning processes will be focused on building an active and flexible environment for students. True knowledge will be found by the students in the most beneficial knowledge for their personal development. To the progressive, the truth will be relative based on students' interpretation of reality.

In progressive education, teachers are facilitators in learning who will encourage students to actively develop their knowledge and skills in self-directed learning.51 Unfortunately, teachers as facilitators have less authority in the classroom. ${ }^{2}$ Students will have freedom over their learning by acquiring knowledge from their personal experiences. Consequently, teachers' beliefs are no more truthful than the students; since both teachers and students are fellow learners who seek knowledge through the school experience. Teachers should facilitate the teaching and learning process with minimal direct teaching to allow students to have a greater responsibility for their own learning. Then, students will be the main focus of learning that will actively direct the learning process in the classroom.

Distinct from the progressive, Christian education mainly focuses on guiding students into the source of knowledge and the absolute truth. God is the center of all understanding of

\footnotetext{
${ }^{51}$ Biesta and Burbules, Pragmatism and Educational Research.

$5^{2}$ Tung, Menuju Sekolah Kristen Impian Masa Kini.
}

\footnotetext{
48 Tung, Menuju Sekolah Kristen Impian Masa Kini. 49 Biesta and Burbules, Pragmatism and Educational Research.

50 Wasitohadi, "Pragmatisme, Humanisme Dan Implikasinya Bagi Dunia Pendidikan Di Indonesia.”
} 
life and the universe; therefore, the fear of the Lord is the beginning of knowledge (Proverbs 1:7; 9:10). The true knowledge of God is provided for humans through Divine revelation in the Bible and His creation. Consequently, Christians view the Bible as the foundation of knowledge that has the authority and sufficient for humans to know their Creator and other creations.53 All knowledge and truth in the universe will point back and be unified in God.54

In conducting every teaching and learning process, Christian education will deeply be rooted in the Bible. Experience, science, and logic will be a complementary means in the process of acquiring knowledge and agrees with the absolute truth in God.55 Moreover, God created humans with a sensus divinitatis, which will enable humans to know Him as the beginning of all things, including knowledge. 56 Sensus divinitatis is the source of the basic knowledge of God that will enable students to believe in God. Therefore, every subject of inquiry should lead students to the knowledge of God.

In addition to that, Christian education views teachers as a guide that leads students into the true knowledge within the Biblical worldview. 57 In contrast with the view of progressive education, teachers need to guide students in the process of unfolding subjects and content in the classroom to see God as the source of knowledge. This suggests that Christian teachers have the responsibility to guide students within the correct perspective of seeing each of them as the image-bearers of God. ${ }^{8}$. The correct view in seeing the students

\footnotetext{
53 Herman Bavinck, Reformed Dogmatics, ed. John Bolt (Grand Rapids: Baker Academic, 2011).

54 Tung, Menuju Sekolah Kristen Impian Masa Kini.

55 Jeynes, The Wiley Handbook of Christianity and

Education.

${ }^{56}$ Sulistio, "Epistemologi Reformed : Sebuah Upaya

Filsuf-Filsuf Kristen Membela Status Epistemologi

Kepercayaan Kristen."

57 Brummelen, Walk. with God Classr.
}

is crucial to provide a framework for Christian teachers to guide students within God's purpose.

The belief that students were created in the image of God who possess God-given intelligence and free-will affects not only teachers' role but also their view of their role. 59 Teachers who view students as God's image bearer see themselves as guides who not only view students as intelligent creatures but also sees their responsibilities to make use of their knowledge to serve God.60 Understanding such roles affects their priorities as well as their learning design. Teachers will, for instance, design learning environment and materials which allow students to build their understanding based on the biblical foundation. To be more specific, teachers may connect all academic disciplines to the true knowledge in God while also developing students' curiosity. Students may participate actively in searching and developing their knowledge, yet teachers need to set the foundation.

As guides, teachers should understand that God created students with free-will but still within the fallen and finite nature. ${ }^{61}$ To help students develop within the right foundation of learning and truth can create a cooperative learning environment in which students could participate actively. However, freedom in students' learning needs to be appropriate. ${ }^{62}$ Students may freely participate in the process of exploring their potential, interest, and in the search of truth, yet still within the Biblical framework. As a guide, teachers have the authority to lead students to the knowledge of God and to limit students' freedom based on the

\footnotetext{
58 Tong, Arsitek Jiwa 1: Guru Sekolah Minggu \& Guru Agama Kristen.

59 Louis Berkhof, Teologi Sistematika: Doktrin Manusia (Surabaya: Momentum, 2006).

60 Bavinck, Reformed Dogmatics.

${ }^{61}$ Berkhof, Teologi Sistematika: Doktrin Manusia.

62 Pazmiño, God Our Teacher: Theological Basics in Christian Education.
} 
Biblical worldview. As in Galatians 5:13 "You, my brothers, and sisters were called to be free. But do not use your freedom to indulge the flesh; rather, serve one another humbly in love (NIV)" freedom should lead to the act of serving God and others. Thus, freedom comes with responsibilities. Teachers have the responsibility to guide the students throughout the learning process and students have the responsibility to use their freedom in learning appropriately.

\section{Conclusion}

In conclusion, progressive education contradicts Christian education in their focus of education which represents the shifting in educational philosophy. Progressive education primarily aims to enrich students' experiences as a means to prepare them for the future. Such educational aim puts teachers' function and roles simply as students' facilitators. As facilitators, teachers will mainly have minimal authority in the classroom as it is students who actively direct their own learning. In other words, students will have freedom in acquiring knowledge within their relative interpretation of truth. There is no absolute foundation in which students could build their knowledge. To the progressitivists, teachers should not direct students to a certain belief, but rather facilitate students' different experiences.

By contrast, Christian education aims at bringing students to the knowledge of God within the Biblical worldview. This aim of education leads to the belief that teachers' role in the classroom is more than just students' facilitator, but rather as students' guide. As a guide, Christian teachers need to emphasize the absolute truth in God throughout all the teaching and learning processes. Teachers' guidance and authority in the classroom is necessary as students are viewed as finite and fallen. Therefore, the focus of learning will be not only on students' personal growth, but in the act of serving God and others. In Christian education, the role of Christian teachers is critical particularly in guiding students through the process of acquiring knowledge and truth within the biblical worldview. In practice, Christian teachers should connect all subject inquiries to the true and absolute knowledge in God. This is what makes Christian teachers' role distinct from the progressive teachers' role.

\section{Research Contribution}

This research helps Christian schools to be more aware of educational philosophy that contradicts Biblical views about knowledge in order for schools to guide students away from relative interpretations of the truth and towards absolute truth.

\section{Further Research Recommendations:}

The authors recommend future researchers to explore other philosophies more in order to compare them to the Christian philosophy so that schools can raise their awareness towards secular influences in education.

\section{Reference}

Anthony, Michael. Introducing Christian Education: Foundations for The Twenty-First Century. Baker Academic, 2001.

Bavinck, Herman. Reformed Dogmatics. Edited by John Bolt. Grand Rapids: Baker Academic, 2011.

Berkhof, Louis. Teologi Sistematika: Doktrin Manusia. Surabaya: Momentum, 2006.

Biesta, Gert, and Nicholas Burbules. Pragmatism and Educational Research. Lanham: Rowman \& Littlefield, 2013.

Brummelen, Haro Van. Batu Loncatan Kurikulum: Berdasarkan Alkitab (2nd Ed.). Jakarta: Universitas Pelita Harapan, 2008.

-- Walking with God in the Classroom. Walking with God in the Classroom. Jakarta: Universitas Pelita Harapan, 2009.

Garte, Rebecca. "American Progressive Education and the Schooling of Poor Children: A Brief History of a Philosophy in Practice." 
International Journal of Progressive Education 13, no. 2 (2017): 7-17.

Gilbert, Marvin. "Integrative Critical Analysis." In Missiological Research: Interdiisciplinary Foundations, Methods, and Integration, edited by Marvin Gilbert, Alan R. Johnson, and Paul W. Lewis, 1st ed., 47-52. Pasadena, CA: William Carey Publishing, 2018.

Graham, Donovan L. Teaching Redemptively: Bringing Grace and Truth into Your Classroom. Colorado Springs: Purposeful Design Publications, 2009.

Habermas, Ronald T. Introduction to Christian Education and Formation: A Lifelong Plan for Christ-Centered Restoration. Grand Rapids: Zondervan, 2008.

HAO, Jian-Jun. "A Study of the Impact of Pragmatism on American Education." DEStech Transactions on Social Science, Education and Human Science, no. icesd (2017): 346-49.

https://doi.org/10.12783/dtssehs/icesd2017/ 11565 .

Jeynes, William. The Wiley Handbook of Christianity and Education. Hoboken: Wiley, 2018.

Knight, George R. Filsafat \& Pendidikan (4th Ed.). Jakarta: Universitas Pelita Harapan, 2009.

Mustapa, Hasan, Riska Maelani, and Iman Saefullah. "Indonesian Human Progressivism : Human Resources Quantity in Educational Philosophy Perspective." Jurnal Pendidikan Universitas Garut 13, no. 01 (December) (2019).

Norris, Norman D. The Promise and Failure of Progressive Education. Lanham: Scarecrow Press/Rowman \& Littlefield Pub, 2004.

Opoku, John Kwaku, Peter Addai-mensah, and Eric Manu. "Realization of the Nature and Role of Christian Education in Modern Pedagogy." British Journal of Education 2, no. 5 (2014): 26-35.

Osman, Ahmed A. "Freedom in Teaching and Learning." International Journal of Humanities and Social Science 3, no. 2 (2013): 142-49.

Pazmiño, Robert W. Foundational Issues in Christian Education. Heritage. Grand Rapids: Baker Academic, 2008.

---. God Our Teacher: Theological Basics in Christian Education. Grand Rapids: Baker
Academic, 2002.

Pecore, John, and Bertram Bruce. "Editorial for Progressive Education: Antecedents of Educating for Democracy." International Journal of Progressive Education 9, no. 1 (2013): 10-13.

Plantinga, Alvin. Faith and Rationality: Reason and Belief in God. Notre Dame: Univ. of Notre Dame Press, 2014.

Radu, Lucian. "John Dewey and Progressivism in American Education." Bulletin of the Transilvania University of Braşov, Series VII: Social Sciences and Law 4, no. 2 (2011): 8590.

Rescher, Nicholas. Epistemology: An Introduction to The Theory of Knowledge. Albany: SUNY Press, 2012.

Sikandar, Aliya. "John Dewey and His Philosophy of Education." Journal of Education and Educational Development 2, no. 2 (2016): 191-201. https://doi.org/10.1080/o0131725309341597.

Snyder, Hannah. "Literature Review as a Research Methodology: An Overview and Guidelines." Journal of Business Research 104, no. August (2019): 333-39.

https://doi.org/10.1016/j.jbusres.2019.07.039

Sukono, Djoko. "Alkitab: Penyataan Allah Yang Diilhamkan.” PASCA : Jurnal Teologi Dan Pendidikan Agama Kristen 15, no. 1 (2019): 28-34. https://doi.org/10.46494/psc.v15i1.66.

Sulistio, Thio Christian. "Epistemologi Reformed : Sebuah Upaya Filsuf-Filsuf Kristen Membela Status Epistemologi Kepercayaan Kristen.” Veritas : Jurnal Teologi Dan Pelayanan 13, no. 2 (2012): 217-29. https://doi.org/10.36421/veritas.v13i2.263.

Suryaningsih, Eko Wahyu. "Doktrin Tritunggal Kebenaran Alkitabiah." PASCA : Jurnal Teologi Dan Pendidikan Agama Kristen 15, no. 1 (2019): 16-22. https://doi.org/10.46494/psc.v15i1.64.

Tong, Stephen. Arsitek Jiwa 1: Guru Sekolah Minggu \& Guru Agama Kristen. Surabaya: Lembaga Reformed Injili Indonesia, 2003.

Tung, Khoe Yoa. Filsafat Pendidikan Kristen: Meletakkan Fondasi Dan Filosofi Pendidikan Kristen Di Tengah Tantangan Filsafat Dunia. Yogyakarta: ANDI, 2013.

---. Menuju Sekolah Kristen Impian Masa Kini. 
Yogyakarta: ANDI, 2014.

Wasitohadi, Wasitohadi. "Pragmatisme, Humanisme Dan Implikasinya Bagi Dunia Pendidikan Di Indonesia.” Satya Widya 28, no. 2 (2012): 175-90.

https://doi.org/10.24246/j.sw.2012.v28.i2.p1 75-190.

Williams, Morgan. "Dewey in the 21 St Century." Journal of Inquiry \& Action in Education 9, no. 1 (2017): 91-102.

Yang, Ferry. Pendidikan Kristen. Surabaya: Momentum, 2018.

Zaluchu, Sonny Eli. "Metode Penelitian Di Dalam Manuskrip Jurnal Ilmiah Keagamaan." Jurnal Teologi Berita Hidup 3, no. 2 (March 25, 2021): 249-66.

https://doi.org/10.38189/jtbh.v3i2.93. 